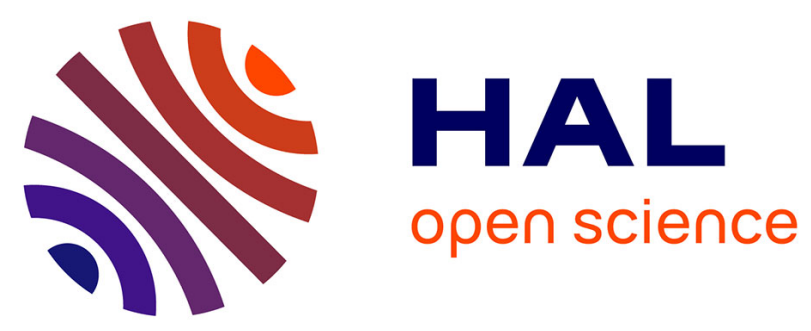

\title{
Apple scab: numerical optimization of a new thermal time scale and application for modelling ascospore release in southern France
}

Christophe Roubal, Philippe C. Nicot

\section{- To cite this version:}

Christophe Roubal, Philippe C. Nicot. Apple scab: numerical optimization of a new thermal time scale and application for modelling ascospore release in southern France. Plant Pathology, 2016, 65 (1), pp.79-91. 10.1111/ppa.12398 . hal-02631243

\section{HAL Id: hal-02631243 \\ https://hal.inrae.fr/hal-02631243}

Submitted on 27 May 2020

HAL is a multi-disciplinary open access archive for the deposit and dissemination of scientific research documents, whether they are published or not. The documents may come from teaching and research institutions in France or abroad, or from public or private research centers.
L'archive ouverte pluridisciplinaire HAL, est destinée au dépôt et à la diffusion de documents scientifiques de niveau recherche, publiés ou non, émanant des établissements d'enseignement et de recherche français ou étrangers, des laboratoires publics ou privés.

\section{(ㄷ)(1) $\$$}

Distributed under a Creative Commons Attribution - NonCommerciall 4.0 International 
Article Type: Original Article

Title: Apple scab: numerical optimization of a new thermal time scale and application for modelling ascospore release in southern France

\title{
C. Roubal ${ }^{\mathrm{a}}$ and P.C. Nicot ${ }^{\mathrm{b} *}$,
}

a'Organisation Nationale de la Protection des Végétaux (ONPV), Quartier Cantarel, BP70095, F-84143Montfavet Cedex, France

${ }^{\mathrm{b}}$ INRA, UR 407 Pathologie végétale, F-84140 Montfavet, France

*corresponding author: philippe.nicot@avignon.inra.fr

Short title: New prediction models for apple scab

\section{Keywords}

Venturia inaequalis, degree-day, primary inoculum, predictive model

\begin{abstract}
Adequate protection of apple trees during the primary contamination period is a cornerstone for the management of apple scab. Correct timing of spring treatments is fundamental and thus, much effort has been devoted to forecasting ascospore release by Venturia inaequalis. Most models rely on degree-day accumulation starting from a biofix date established yearly on the basis of biological observations. Here, we explored the potential interest of using a single calendar date as a biofix and new types of time scales, with the help of numerical This article has been accepted for publication and undergone full peer review but has not been through the copyediting, typesetting, pagination and proofreading process, which may lead to differences between this version and the Version of Record. Please cite this article as doi: 10.1111/ppa.12398

This article is protected by copyright. All rights reserved.


optimization with field-collected data. Using data acquired between 1996 and 2008, we assessed the daily rate of development for $V$. inaequalis primary inoculum by fitting generic time scale functions, a method which requires the smallest number of assumptions about the effect of temperature on the biological phenomenon. An optimal calendar biofix was established for Provence and the use of non-linear functions relating pseudothecial development rate to temperature for accumulating thermal time was compared with the usual linear response in standard degree-day models. A model was then constructed using 4 additional years of data for validation. The predictive value of the model was further improved by adjusting the time scale with "accelerating rules" to take into account the positive influence of rainy days on pseudothecial maturation prior to ascospore release. However, halting rules inserted in the time scale to account for dry days during the ascospore release period strongly reduced the predictive value of the model in the conditions of Southern France, suggesting the possible occurrence of strains adapted to dry conditions.

\section{Introduction}

Venturia inaequalis, the causal agent of apple scab, is of major economic concern for apple production and its control entails a large number of fungicidal treatments (Carisse et al., 2007 , 2009). It was estimated that $75 \%$ of pesticide use on apples aims at controlling fungal diseases and $70 \%$ of those fungicide treatments target apple scab (Creemers \& Laer, 2006). Treatments against apple scab typically start in early spring to protect the first unfolding leaves against primary inoculum which consists mostly of ascospores (Stensvand et al., 1997). If early treatments are not successful, secondary inoculum (consisting of conidia) is produced on diseased tissue and polycyclic epidemics may develop in the orchard, requiring numerous additional treatments during the growing season (Carisse et al., 2009). Conversely, if disease development is prevented until the ascospore supply is depleted in early summer,

This article is protected by copyright. All rights reserved. 
subsequent fungicide sprays against scab may be reduced and, in some cases, omitted altogether (Stensvand et al., 2005). This is the general situation in Southern France, although complicating factors such as airborne contamination from neighbouring orchards or overwintering of conidial inoculum have been reported in other parts of Europe (Holb et al., 2005). The pathogen is known to overwinter primarily as pseudothecia present on leaf litter. During this period, the pseudothecia undergo a progressive maturation process, which results in the release of ascospores in the spring, a phenomenon which has been shown to be triggered by rain events (Rossi et al., 2000).

Much research effort has been dedicated to predicting the beginning and the end of the presence of primary inoculum, as well as the dynamics of ascospore release on the basis of climatic factors (Holb, 2008). Numerous models have been developed to predict the dynamics of maturation and release of this inoculum. These models have been based on thermal time scales rather than physical time scales (Lovell et al., 2004). The basis for this concept is that the kinetics of biological phenomena are influenced by temperature and in apple scab models, thermal time was defined as the accumulation of a temperature function relating the pseudothecial maturation rate to temperature. The "New Hampshire (NH) model" developed by Gadoury \& MacHardy (1982a) and others derived from it (Stensvand et al., 2006a; Schwabe et al., 1989; Lagarde, 1988), have provided useful tools for apple growers worldwide. The NH model was built by fitting a linear regression equation to Probit-transformed data on the percentage of mature ascospores plotted against a thermal time scale consisting of degree-day accumulation (base $=0^{\circ} \mathrm{C}$ ) from the first appearance of ascospores in the spring. This Probit regression approach, used to select the most appropriate degree-day base (among possible temperatures between 0 and $6^{\circ} \mathrm{C}$ ), relied on the assumption that the law relating pseudothecial maturation rate to degree-day accumulation was a 
Gaussian function. After a reverse Probit transformation, a sigmoid curve was then obtained and used for the prediction of ascospore release based on degree-day accumulation, starting at a date commonly referred to as "biofix" (Gadoury \& MacHardy, 1982a). This type of thermal time scale and the use of degree-days as a temperature function have been largely adopted worldwide.

Successful prediction of ascospore release has sometimes required adjustments to the specific shape of the maturation curve to fit local data (Schwabe et al., 1989; Stensvand et al., 2006a). The need for such adjustments could be related to the influence of climate factors not taken into account by the initial NH model (Xu et al., 1995; Rossi et al., 2000; Stensvand et al., 2005, 2006a, 2006b). For example, predictive improvements have been obtained by taking into account an effect on pseudothecial maturation of long dry periods during ascospore release (Rossi et al., 2000; Stensvand et al., 2005, 2006a) and of the occurrence of rain before the ascospore release period (Stensvand et al., 2006b). Another possible explanation could also be that the use of degree-days does not constitute an optimal time scale for predictions. For example, in the model developed by James \& Sutton (1982a, 1982b) to describe pseudothecial maturation and predict ascospore release, the best predictions were achieved when using time scales defined as sums of second order polynomial functions of temperature, rather than the degree-days which represent a simple first order function. Although time scales based on non-linear temperature functions are routinely used for modelling in several fields of research, including the description of insect pest development (Damos \& Savopoulou-Soultani, 2012), they have rarely been used for plant pathogenic fungi until recently (Xu, 1996; Legler et al., 2012; Battilani et al., 2013). Notable exceptions include the foundational modelling work of Analytis (1977) on the development of ten pathogenic fungi. As pointed out by Xu (1996) the response curves that 
relate the rate of development of a fungal pathogen to temperature are bell-shaped, rather than linear.

Another method to improve the predictions provided by the $\mathrm{NH}$ model has relied on using different types of biofix. In the original $\mathrm{NH}$ model, the biofix corresponded to the first observation of mature ascospores in pseudothecia collected from leaves stored on the ground in wire-mesh baskets (Gadoury \& MacHardy, 1982a). Other types of biofix used by different workers were the date of first detection of ascospores in spore traps or dates selected on the basis of the phenological growth stages of the trees (for example bud break) (Stensvand et al., 2005). However, all these methods provided somewhat variable results and their application for regional predictions has often been a topic of controversial discussions between advisers (Creemers \& Laer, 2006, Eikemo et al., 2010). An alternative type of biofix, a fixed calendar date, was used by Beresford in New Zealand (1999). This calendar-based biofix presented the advantage of combining simplicity and pertinence.

The first two objectives of the present study were (i) to evaluate the benefit of a thermal time scale that uses a nonlinear function to relate the rate of pseudothecial maturation of $V$. inaequalis to temperature, and (ii) to define a calendar-based biofix. The resulting optimized thermal time scale, based on a corpus of biological and on meteorological field data acquired over a 13-year period, was then used to construct a predictive model of ascospore release. This model was then validated with independent data of four additional growing seasons. A final objective of the present study was to explore possible predictive improvements by taking into account an effect on pseudothecial maturation of long dry episodes during the ascospore release period and of the occurrence of rain before this period.

This article is protected by copyright. All rights reserved. 


\section{Materials and Methods}

\section{Pseudothecial maturation and ascospore release.}

From 1996 to 2013, batches of approximately 1000 scabbed leaves were collected in autumn from organic orchards (cv Golden delicious) located in the vicinity of Avignon in the Rhône Valley. Each year, one orchard was selected on the basis that no pesticide treatment had been applied and that apple scab had been prevalent during the season (20\%-90\% of leaves showing scab spots). Collected leaves were brought back to the station of the Organisation Nationale de la Protection des Végétaux and arranged on the ground over a $1 \mathrm{~m}^{2}$ area under chicken wire, 5 meters from an agrometeorological station belonging to the network of the French Ministry of Agriculture (GPS coordinates 43.908228, 4.883370). The leaves were examined regularly for possible degradation by earthworms or other organisms feeding on litter. Earthworm degradations were never observed but application of metaldehyde on the perimeter of the area was necessary as a barrier against slugs and snails. Starting in early January, random samples of approximately 50 leaves were collected every week and observed under a stereo microscope (20-40 magnification) to detect the presence of pseudothecia. Following the detection of the first pseudothecia (usually in late January), leaf samples were collected 1-3 times a week and a total of 50 pseudothecia were crushed and examined under the microscope (magnification 100-200) each time for presence of asci and ascospores. Ascospore maturity was assessed on the basis of their morphology and pigmentation as described by Gadoury \& MacHardy (1982b). Each year, the date of the first observation of mature ascospores was then used as reference "biofix" in the modelling work.

Ascospore release was quantified on batches of glass slides placed on the chicken wire over the leaves and renewed (in the same positions) after each rain. Within one day after a rain event, 10 glass slides were observed under the microscope and the ascospores

This article is protected by copyright. All rights reserved. 
were counted on each slide on 7 replicate zones, each $2 \mathrm{~mm}$ high and $22 \mathrm{~mm}$ long. These observations were carried out from the first detection of differentiated asci in the pseudothecia, until the time when no more ascospores were detected on the glass slides for several consecutive rain events (usually end of May). To ensure that further release would not escape detection after the end of the observation period, a final ascospore count was carried out following an artificial rain episode achieved by sprinkling the leaves and keeping them wet for three successive days. To compare the dynamics of ascospore release over different years, the numbers were expressed as a percentage of the total yearly spore counts (Gadoury \& MacHardy, 1982a).

\section{Weather data}

Data were collected from the agrometeorological station mentioned above. This CIMEL 140 device (CIMEL Electronique, Paris, France) was positioned at a height of $1.50 \mathrm{~m}$ above the ground and recorded air temperature every 20 minutes. The output consisted of daily averages, each computed with 72 data values. Over the period from 1996 to 2013, a total of 5173 averages were computed and these daily averages ranged from $-5^{\circ} \mathrm{C}$ to $26^{\circ} \mathrm{C}$ between 1 September and 31 May, with $98 \%$ of the values between $3{ }^{\circ} \mathrm{C}$ and $20^{\circ} \mathrm{C}$. The weather station also recorded hourly rain intensity with a $0.2 \mathrm{~mm}$ tipping bucket rain gauge.

\section{Construction of a generic thermal time scale and selection of a calendar biofix}

To investigate new temperature functions describing the relationship between the daily rate of pseudothecial maturation $\mathrm{R}$ and the average daily temperature $T$, we chose not to select arbitrarily a specific mathematical function. Instead, we based our approach on the basic hypothesis that $\mathrm{R}(T)$ is equal to zero for $T$ below a minimum threshold, it increases to a maximum value with increasing $T$ and then decreases to become null when $T$ is higher than a

This article is protected by copyright. All rights reserved. 
maximum temperature threshold. A simple proteiform function, describing with a limited number of parameters the general shape of such a unimodal curve, consists of a succession of five linear segments as described in Figure 1. This generic function, referred to as "ABCD" function in the present study, is described with four parameters $a, b, c$ and $d$ (Table 1). It allows approximation of the possible asymmetry and "peakness" of the unknown $\mathrm{R}(T)$ function describing the actual complex biological phenomena and to estimate the value of $T$ for its maximum. Interestingly, the degree-day temperature function of the NH model represents a particular case of the $\mathrm{ABCD}$ function, with $a=0$ and a linear rate increase with increasing temperature.

Using 11 sets of experimental data collected from 1996 to 2008, the ABCD temperature function was optimized and parameterised as described below. In the same time, to explore the pertinence of using a calendar biofix, 19 biofix dates (approximately at a 10-day interval) were evaluated, between 1 September and 1 March.

Parameterisation of the temperature function. The parameterisation of the temperature function was carried out with a method that does not require prior knowledge of the underlying temperature response of the pseudothecial maturation. This approach was used to avoid the a priori selection of an arbitrary function relating spore release to the thermal time scale (as done previously for the NH model [Gadoury \& MacHardy, 1982a]), when trying to define the most appropriate rate response to temperature for pseudothecial maturation. Our method relied on the fact that the function we ultimately sought, for the prediction of cumulated spore release, is a strictly increasing function of the thermal time. This allowed us to optimize the parameterisation of temperature functions using Spearman's rank correlation $\rho$ (Sheskin, 2007), which is commonly used to assess the monotonic 
relationship between two variables (Zou et al., 2003). In the context of our study, $\rho$ was defined as:

$$
\boldsymbol{\rho}=1-\left(6 * \Sigma\left(\mathrm{r}_{\text {thermal time }}-\mathrm{r}_{\text {ascospore release }}\right)^{2} /\left(\mathrm{n} *\left(\mathrm{n}^{2}-1\right)\right)\right.
$$

where $\mathrm{n}$ was the number of data points (days of ascospore release) in the data set, and $\mathrm{r}_{\text {thermal }}$ time (abbreviated as $r_{t s}$ ) and $r_{\text {ascospore release }}$ (abbreviated as $r_{a r}$ ) were, respectively, the ranks of a given data point on the $\mathrm{X}$ axis (the thermal time) and on the $\mathrm{Y}$ axis (representing the cumulated percentage of released ascospores). If $\boldsymbol{\rho}$ is computed for the data of a single year, its value is necessarily 1 , as the ranks increase together for the thermal time $\left(\mathrm{r}_{\mathrm{ts}}\right)$ on the $\mathrm{X}$ axis and for the $\mathrm{Y}$ axis $\left(\mathrm{r}_{\mathrm{ar}}\right)$. When computing $\boldsymbol{\rho}$ for the data of several years, its value is $\leq 1$, because the overall ranks do not necessarily increase together. Thus, the more pertinent a temperature function is, for calculating thermal time over all years, the more the ranks $r_{t s}$ and $\mathrm{r}_{\mathrm{ar}}$ will increase together when examining the complete 11-year data set. For a given temperature function, the most pertinent set of parameters should thus be that for which $\boldsymbol{\rho}$ takes a value closest to 1 . In other words, a value of $\boldsymbol{\rho}$ nearest to 1 characterizes the parameters for which the cluster of data points is closest to the ideal and unknown curve that describes the dynamics of cumulated spore release.

Selection of a biofix. For each of the 19 biofix dates, large numbers (> 100000) of different sets of parameter values (representing combinations of $a, b, c$ and $d$ values between -20 and 40) were tested, using the algorithm shown in Figure 2. Such approach could also be useful for parameterising a wide range of biological models. For a given biofix date, the set of $a, b, c$ and $d$ values providing the highest $\boldsymbol{\rho}$ was considered as the set of optimized parameters. To respect the definition of the ABCD function, only sets of values respecting the following relationship were evaluated: $a<b$ and $b \leq c$ and $c<d$.

This article is protected by copyright. All rights reserved. 
To select the most pertinent calendar biofix among the 19 dates tested, we examined the associated $\boldsymbol{\rho}$ values (Figure 3). Two additional computations were realized to ensure that our choice was not biased by any calculation artefacts. Firstly, the parameterisation step described above was carried out and the corresponding $\boldsymbol{\rho}$ values were computed for additional dates surrounding the selected biofix (each day from 20 December to 10 January). This allowed the stability of the $\boldsymbol{\rho}$ values in this period to be verified. Secondly, the parameterisation step described above was also carried out and the corresponding $\boldsymbol{\rho}$ values were computed for the 19 biofix dates, using a modified Gauss function (Table 1) as a temperature function (using 8000 sets of parameters for each date). This determined whether the best biofix date, using thermal time based on the ABCD function, was similar to that using the other temperature functions.

The selected biofix date was then used to compare the ABCD temperature function to other $\mathrm{R}(T)$ functions with similar shapes and to the degree-day function used in the reference $\mathrm{NH}$ model (Gadoury \& MacHardy, 1982a).

\section{Comparison of thermal time scales}

Based on the shape of the parameterised $\mathrm{ABCD}$ temperature function, two continuous mathematical functions were selected for comparison, among those previously used for the description of curves with such shapes (Kontodimas et al., 2004; Jalali et al., 2010): the model proposed by Analytis (1979) to describe fungal development and the modified Gauss function as shown in Table 1. These two additional temperature functions were optimized and parameterised using the same algorithm as described above. In addition to the degreeday function used in the reference NH model, comparisons were also carried out (Table 1) with a $2^{\text {nd }}$ order polynomial function (Figure 1) as proposed by James \& Sutton (1982b) to 
relate average daily temperature to pseudothecial maturation rate. The thermal time scales based on all these temperature functions were compared on the basis of Spearman's rank correlation $\boldsymbol{\rho}$ as described above. The time scale providing the highest value of $\boldsymbol{\rho}$ was retained for the rest of the study.

\section{Construction and validation of a predictive model for ascospore release}

Based on the $\mathrm{ABCD}$ function described above, a model was constructed to fit ascospore release as a function of thermal time. Using 11 data sets from 1996 to 2008, regression analysis was carried out with the Levenberg-Marquardt algorithm (Marquardt, 1963) to parameterise the 33 possible functions proposed by the CurveExpert 1.3 software (http://www.curveexpert.net). Residual analysis and a Student's T test were used to compare the fit of this ABCD-based model with that of a reference NH-based model adapted to climatic conditions and dynamics of ascospore release of southern France (Lagarde, 1988).

The ABCD-based model was then validated with data sets of 2009, 2011, 2012 and 2013 and its predictive value was compared to that of the reference NH-based model. The models were compared on the basis of the size and distribution of residuals and on the frequency of overand under-estimation of observed ascospore release data.

\section{Adaptation of the thermal time scale to the occurrence of dry and rainy periods}

To take into account the possible slow-down effect of prolonged dry periods on the release of ascospores, halting rules (Stensvand et al., 2005) were applied to the thermal time scales. They consisted in suspending the accumulation of daily rate of pseudothecial maturation when 7 dry days occurred consecutively.

This article is protected by copyright. All rights reserved. 
As the occurrence of rainy days before the onset of ascospore release was also reported to influence the maturation process (Stensvand et al., 2006b), this phenomenon was investigated in the context of Southern France. For this, the relation between the number of rainy days before ascospore release and the estimated date of its onset was examined through regression analysis, using data sets from 1996 to 2008.

In a first step, the period considered for the quantification of rainy days was defined as the month preceding the first ascospore maturity and the minimal amount of recorded rain needed for a day to be considered as "rainy" was $0.2 \mathrm{~mm}$ (Stensvand et al., 2006b). The onset of ascospore release was assessed as the date when $10 \%$ of cumulated ascospore release was reached. This date was estimated each year by linear interpolation from the observed data. Only 10 of the 11 data sets were used at this stage, as the dynamics of ascospore release did not allow an accurate interpolation in 2000. On that year, the first rain occurred 40 days after the observation of the first mature ascospores and resulted in the sudden release of $41 \%$ of the total ascospore stock (Figure 4). The 10 years were ranked according to the timing of estimated $10 \%$ ascospore release dates. Regression analysis was then carried out on the number of rainy days of a year vs its rank for ascospore release.

In a second step, the relation between the number of rainy days before ascospore release and the estimated date of its onset was refined. For this, the minimal amount of recorded rain needed for a day to be considered as "rainy" was adjusted (among 29 threshold values between 0.2 and $3 \mathrm{~mm}$ ) to optimize the fit of the regression line. These optimized threshold and regression line were then used to adjust the $\mathrm{ABCD}$ thermal time scale. The adjustment consisted in adding an "acceleration term" $v^{*} R D$ to the cumulated daily rate of pseudothecial development, where $R D$ represented the number of rainy days and $v$ an acceleration 
coefficient. The value of $v$, and the two dates defining the period influencing the timing of the onset of ascospore release were established, applying the same algorithm of numerical optimization used above to parameterize the $\mathrm{ABCD}$ thermal time scale. In this case, the link between the ascospore release dynamics and the thermal time was assessed for all possible values of $v$ and all dates between 9 December and 9 March. Again, it relied on Spearman's rank correlation $\rho$ which allowed the comparison of continuously increasing temperature functions of thermal time scales without any knowledge about the specific shape of the ascospore release curve. The optimized parameters providing the highest $\boldsymbol{\rho}$ value were used to define an improved "rain sensitive" ABCD thermal time scale, referred to in the rest of this paper as "rABCD" thermal time scale. This new thermal time was then used to construct a new predictive model for ascospore release.

\section{Construction and validation of an adjusted model for ascospore release}

Based on the $\mathrm{rABCD}$ function, a new model was constructed to fit ascospore release as a function of time. The same regression method was used as described above for the construction of the basic ABCD-based model with functions proposed by the CurveExpert 1.3 software. Residual analysis and a Student's T test were then used to compare the fit of this adjusted rABCD-based model with that of the basic ABCD-based model.

The rABCD-based model was then validated with data sets of 2009, 2011, 2012 and 2013 and its predictive value was compared to that of the basic ABCD-based model. They were compared on the basis of residual analysis and a Student's T test. .

This article is protected by copyright. All rights reserved. 


\section{Results}

\section{Observed ascospore release}

Over the 13 years of observations, the first mature ascospores were recorded over a broad range of calendar dates, spanning from 7 February to 27 March (Table 2). The first and last dates of ascospore release also varied widely over the years. The total numbers of ascospores counted over a season varied from less than 500 to over 48000 . Due to the low spore counts, the data from 1998 and 2003 were not considered as sufficiently reliable and were not retained for further analysis. Another year (2000) was somewhat atypical with a 40-day long dry period after the first observation of mature ascospores, which resulted in the release of $41 \%$ of the yearly ascospore potential at the first rain. This year was retained for modelling, to take into account the widest possible range of climatic variability.

\section{Choice of a biofix}

Compared to the biofix of the NH model (first observation of mature ascospores), for which the $\boldsymbol{\rho}$ value was 0.9229 , calendar values of the biofix between 1 September and 20 December resulted in lower $\boldsymbol{\rho}$ values of the ABCD thermal time scale (Figure 3). However, higher or similar $\boldsymbol{\rho}$ values were observed for biofix dates between 1 January and 20 February. These changes coincided with sharp increases in the values of parameter " $a$ " of the ABCD temperature function. For a biofix on 1 March (and later; data not shown), the $\rho$ value decreased sharply. For the rest of the study, the date of 1 January was used as biofix for all temperature functions except the NH model, which was tested both with a 1 January biofix and with its reference biofix (first observation of mature ascospores). The choice of 1 January as a biofix (rather than 20 February, which provided a slightly higher $\boldsymbol{\rho}$ value) was motivated by the fact that starting the prediction model at the later date would entail a risk of missing ascospore maturation for years with mild winters. Furthermore, biological data show

This article is protected by copyright. All rights reserved. 
that the observation of the first ascospore release is preceded by various stages of a maturation process which can start as early as the first week of December (James \& Sutton, 1982a, Gadoury et al., 1984). The $\boldsymbol{\rho}$ values for the eleven days before and nine days after 1 January did not show a high level of variability (Figure 5). Furthermore, a biofix of 1 January was also the best when using a modified Gauss function as a temperature function (Figure 5).

\section{Comparison of thermal time scales}

With this 1 January biofix, higher $\rho$ values were obtained with all thermal time scales based on non-linear temperature functions than with the NH model (Table 1). The $\boldsymbol{\rho}$ value of the $\mathrm{NH}$ model remained low when taking the date of the first observation of mature ascospores as a biofix. The ABCD function and the two continuously differentiable functions with similar shapes (modified Gauss and Analytis) all had very similar $\boldsymbol{\rho}$ values. These three functions also had a shape similar to that of the function established by James \& Sutton (1982b), which presented a slightly lower but comparable $\boldsymbol{\rho}$ value (Table 1).

\section{Predictive model for ascospore release, using the parameterised ABCD thermal time scale}

Based on regression analysis, the best fit to the 11 ascospore release datasets $\left(R^{2}=0.91\right)$ were obtained with Richard's law (defined as $y=\alpha /\left[1+\exp \left(\beta-\gamma^{*} x\right)\right]^{\wedge}(1 / \delta)$, where $y$ and $x$ are the percent of total ascospore release and the daily accumulation rate for thermal time using the $\mathrm{ABCD}$ temperature function, respectively) with parameters $\alpha=100, \beta=10.3975, \gamma=0.1053$ and $\delta=1.1586$. The predicted ascospore release (Figure 4) did not underestimate the beginning (one minor exception in 1996) nor the end of the risk period represented by the observed presence of ascospores between 1996 and 2008. The distribution of residuals of this ABCD-

This article is protected by copyright. All rights reserved. 
based model being modal and approximately bell-shaped, we used a Student test to compare its fit to that of the reference NH-based model. The residuals of the NH-based model were significantly higher than those of the ABCD-based model $(P<0.01)$.

\section{Model validation with four independent data sets from 2009 to 2013}

The ABCD-based predictive model and the reference NH-based model were used to forecast ascospore release from 2009 to 2013. Predicted values were compared to observed ascospore counts in 2009, 2011, 2012 and 2013. Neither model predicted ascospore release very accurately (Figure 6), with absolute values of maximum residuals as high as 64.4 (2 April 2011) and 32.5 (17 April 2012) for the reference and the ABCD-based models, respectively (Table 3). The NH-based model regularly overestimated the cumulated percentage of released ascospores (2 exceptions among 48 observations between 2009 and 2013). In contrast, the residuals for the ABCD-based model were not systematically positive and the overall amplitude of the deviation was always smaller (Table 3). For three of the four years, both the average residual values and the averages of the absolute values of the residuals were remarkably smaller for the $\mathrm{ABCD}$-based model. The residuals of the NH-based model were significantly higher than those of the ABCD-based model $(P<0.01)$.

\section{Taking into account periods of dryness during the ascospore release period}

Halting rules, applied to the reference $\mathrm{NH}$ and the $\mathrm{ABCD}$ thermal times scales to account for possible reduction in ascospore maturation during dry days, resulted in lower values of Spearman's rank correlation index (Table 4). The effect was most substantial for the ABCD than for the NH thermal time scale, but in both cases, this indicated that the introduction of these halting rules had no potential to improve the predictive models in the conditions of our study.

This article is protected by copyright. All rights reserved. 


\section{Taking into account rainy events before the ascospore release period}

The onset of ascospore release between 1996 and 2008 was significantly affected $(\boldsymbol{P}<0.05$; $\left.\mathrm{R}^{2}=0.80\right)$ by the occurrence of rainy events in winter. Maturity was increasingly delayed with decreasing occurrence of rain. Figure 7 shows this relationship for a recording period of rainy days from 13 January to 21 February and a rain threshold of $2.5 \mathrm{~mm}$. The most pertinent relationships were obtained with rain thresholds between 1.5 and $3 \mathrm{~mm}$, with an optimum for 2.5. The fitness of the regression lines decreased clearly below $1.5 \mathrm{~mm}$ and beyond $3 \mathrm{~mm}$ (data not shown). Taking this phenomenon into account led to the implementation of an "acceleration rule" for the daily rate of ascospore development in the $\mathrm{ABCD}$ thermal time scale. It consisted of adding $2.1 \times R D$ to the cumulated daily rate of pseudothecial development, 2.1 being the optimized value of the acceleration coefficient $v$ and $R D$ representing the number of days with a rain $\geq 2.5 \mathrm{~mm}$ during the period between 13 January and 21 February. These values and dates were optimized from the comparison of all possible combinations of 28 rain threshold values with 40 values of $v$ and all possible starting and ending dates of the rain recording period between 9 December and 9 March. Figure 8 shows one example of such comparisons for all possible starting and ending dates with the particular case of a rain threshold of $2.5 \mathrm{~mm}$ and $v=2.1$. For each pair of dates, the $\boldsymbol{\rho}$ values evaluate the relationship between the thermal time and the cumulated percentage of released ascospores. These optimized parameters provided the highest $\rho$ value $(0.945)$ and were used to define the rain sensitive $\mathrm{rABCD}$ thermal time scale, which in turn was used for the construction of the new predictive model for ascospore release.

This article is protected by copyright. All rights reserved. 


\section{Improved prediction of ascospore release, using the $\mathrm{ABBCD}$ thermal time scale}

Based on regression analysis, the best fit to the 11 ascospore release datasets $\left(R^{2}=0.98\right)$ was obtained with Richard's law with parameters $\alpha=100, \beta=13.5930, \gamma=0.1343$ and $\delta=0.5629$. Based on Student's $\mathrm{T}$ test, the residuals of this rABCD-based model were significantly smaller than those of the initial ABCD-based model $(P<0.05)$.

Using the datasets from 2009 to 2013 for a validation step, the rABCD-based model improved the accuracy of ascospore release predictions compared to both the reference $\mathrm{NH}$ model and the ABCD-based model (Figure 6). The improvement was most substantial for 2009 with predicted values very close to observed values. For all years, the overall amplitude of the deviation and the average of absolute values of the residuals were always smallest for the rABCD-based model (Table 3). Based on Student's $\mathrm{T}$ tests, the absolute values of the residuals of the $\mathrm{rABCD}$-based model were significantly smaller than those of the initial ABCD-based model $(P<0.001)$, which in turn were significantly smaller than those of the reference NH-based model $(P<0.001)$.

\section{Discussion}

The present study highlighted two potential improvements for the field prediction of ascospore release of $V$. inaequalis. One concerns the thermal time scale and the other concerns the biofix.

Based on 11 years of field data, all non-linear functions tested in this study provided thermal time scales with a better link between observed and predicted ascospore release than the reference degree-day thermal time scale (Table 1). Interestingly, the values of Spearman's rank correlation index was similarly high for all these non-linear functions, whether

This article is protected by copyright. All rights reserved. 
parameterised through numerical optimization of field data in the present study $(A B C D$, Gauss and Analytis functions) or derived from experiments conducted in controlled conditions such as the equation of James \& Sutton (1982b). This suggests that all these nonlinear functions would be of interest for the development of predictive models. For the further development of decision support systems, preference might be given to those functions that are continuously differentiable, as they present the advantage of a smooth distribution usually associated with biological phenomena.

Past studies on $V$. inaequalis have relied on laboratory work to establish daily rates of development at specific constant temperatures in growth chambers. One significant feature of the method used in the present study is that it allowed us to make direct use of field data to describe the relationship between the daily rate of development and temperature. Interestingly, the optimised $\mathrm{R}(T)$ functions that we obtained took positive values with mean daily temperatures slightly below $0^{\circ} \mathrm{C}$. This suggests that even a few hours of positive temperature during a day may be sufficient to allow ascospore development. This hypothesis is coherent with the strategy developed by Rossi et al. (2000) to construct a predictive model using hourly temperature data. Alternatively, this result could also stem from differences in microclimate between the weather-recording station and the leaf litter under study. These considerations highlight possible difficulties for the application of laboratory-generated data (usually at constant, well controlled temperatures) to construct field prediction tools.

The second key result of our study is that using a fixed calendar biofix as the starting date of the thermal time can provide equivalent or better prediction capacity than using the date of first observation of mature ascospores in the spring. This simplification presents several advantages for practical field implementation of the predictions. First, it removes the 
need to determine the date of appearance of mature ascospores in the spring. Thus it can save local advisory services substantial logistical effort and requirements for qualified labor to collect field samples of pseudothecia and examine ascospores under the microscope at least twice a week for 3-4 weeks in January-February each year. Secondly, it removes the uncertainties regularly encountered by local services concerning the representativeness of their field samples and possible imprecision associated with sample size. Thirdly, a biofix of 1 January largely anticipates the first observation of mature ascospores (by 1-1.5 month in Southern France). A benefit of this early biofix in comparison with other methods, including those based on the phenological stage of the trees in the spring (Stensvand et al., 2006a), is that it allows the models to take into account possible effects of climatic parameters on a wider number of pseudothecial maturation phases, including those early phases evoked by James \& Sutton (1982a, 1982b). Furthermore, recent work has shown that in a region with warm winter temperatures, ascospore release occurred earlier than bud break (Alves \& Beresford, 2013). This situation rendered inappropriate the use of bud break as a biofix, because it resulted in underestimating the early risks of ascospore release, and a calendar date was recommended for prediction models. Other workers have reported a lack of coincidence between the phenological stages of the apple tree and developmental stages of the pathogen. For example, a temperature of $0^{\circ} \mathrm{C}$ is used as the basis for the computation of scab degreedays in the $\mathrm{NH}$ model (Gadoury et al., 1982a), whereas a temperature of $5^{\circ} \mathrm{C}$ was reported as the basis for leaf emergence on apple trees (Carisse et al., 2007).

Interestingly, the present study allowed to identify a period when temperature appeared to have little effect on pseudothecial maturation, as shown by the lower values of Spearman's rank correlation coefficient obtained for biofix dates before 20 December (Figure 3). This could thus correspond to the end of the dormancy period of pseudothecia described before by

This article is protected by copyright. All rights reserved. 
several authors for $V$. inaequalis (James \& Sutton, 1982a, 1982b) or V. pyrina (Rossi et al., 2009). Clearly, the optimized date of 1 January found in the present study for the calendar biofix was based on local climatic conditions in Southern France and may require adaptation in other regions. Furthermore, different calendar biofix dates would obviously be appropriate in the southern hemisphere. Adaptation might also be needed to local pathogen populations and apple cultivars.

The interest of combining a calendar biofix and a non-linear response to temperature for pseudothecial maturation ( $\mathrm{ABCD}$ function in the present case) was confirmed with the construction of a predictive model, using 11 years of field data from Southern France, and its evaluation with four additional independent data sets from 2009 to 2013 . The ABCD-based model provided significantly better predictions of ascospore release than the reference NHbased model, for the 11 data sets used for model construction. It also provided better fit to the data for all of the four years used for model validation, including two atypical years (2012 and 2013) for which ascospore release occurred several weeks later than usual, at a period when growers traditionally tend to interrupt spray programs against apple scab. In Provence, cessation of chemical treatments is typically recommended by local advisors for orchards where chemical control is fully successful year after year, if no disease has occurred when an estimated $90 \%$ of the ascospore load has been released. Overall for the four years of validation in our study, advice based on such a decision threshold together with the $\mathrm{NH}$ model would have incited the growers to suspend treatments too early and resulted in an absence of protection of the orchards against one to three infections per year (ascospore releases of 26 April 2009; 27 April and 5 May 2010; 4, 8, and 20 May 2012; 29 April and 5 May 2013; Figure 6). Conversely, using the ABCD-based model would have resulted in protection of the orchard on all these dates, but it would also have led to a treatment advice

This article is protected by copyright. All rights reserved. 
against the ascospore release of 12 May 2009, which was not justified (Figure 6). The benefit of the ABCD-based model in the conditions of Southern France could be due to the fact that temperatures are usually high in late spring at the end of the ascospore release period, resulting in a fast accumulation of degree-days. In such conditions, the NH-based model tends to over-evaluate the daily rate of pseudothecial maturation. In contrast, the $\mathrm{ABCD}$ thermal time scale takes into account the actual reduction in the daily rate of pseudothecial development as described by James \& Sutton (1982a, 1982b).

The third major result of the present study is the significant improvement in the predictive value of the model, obtained by adjusting the thermal time with "accelerating rules" to take into account the positive influence of rainy days on pseudothecial maturation prior to ascospore release. The most useful improvements of this "rain sensitive" rABCDbased model consisted in a generally more accurate prediction of the beginning and ending of the ascospore release period, as those two phases are of crucial importance for scab management. For example, the unnecessary treatment of 12 May 2009 mentioned above would not have been prescribed when using the rABCD-based model (Figure 6). Similarly, the $\mathrm{rABCD}$-based model would have saved an unnecessary treatment (prescribed both by the NH- and ABCD-based models) against the ascospore release of 27 March 2011 (Figure 6). In comparison to the basic ABCD-based model, the rABCD-based model carries a similar level of security but a reduced frequency of risk overestimation.

The basis for the establishment of the "accelerating rules" of the rABCD thermal time scale in this study is the evidence for a strong link between the number of rainy days at the end of winter and a delay in ascospore release. Such a relation was first described for the 30day period before bud break in a large study involving 21 orchards of 11 countries, including 
France (Stensvand et al., 2006b). The algorithm of numerical optimization applied in the present study to 11 years of field data in Provence established a rain sensitivity period of comparable length and timing, from 13 January to 21 February. However, the optimal daily rain threshold provided by the algorithm $(2.5 \mathrm{~mm})$ was substantially higher than that of the original study (0.2 mm; Stensvand et al., 2006b). Specific reasons for this difference are not known, but could possibly be due to low rainfall producing limited wetting of leaf litter in the particularly dry and windy climate of Provence.

An intriguing result of the present study is that adjusting the thermal time with halting rules, to take into account the possible effect of dry days during the ascospore release period, did not improve the predictive value of the models in the conditions of Southern France. The most illustrative year was 2000 , for which no rain event occurred within the 40 days that followed the observation of the first mature ascospores. On that year, the total amount of captured ascospores was the smallest in the 15 datasets used in this study (total of 610 spores observed, compared to a maximum of 48443 in 2004), but the first rain triggered the release of $41 \%$ of the total stock (Figure 4). Halting the thermal time during that long dry period would have led to provide farmers with an erroneous "low risk" advice. This absence of improvement when using halting rules in our region was quite surprising because their introduction provided important progress in scab prediction in various countries (Rossi et al., 2000; Stendsvand et al., 2006a). Furthermore, using halting rules for the pear scab model described by Eikemo et al. (2011), we obtained substantial improvement in the prediction of Venturia pyrina ascospore release for four data sets over three French regions, including Provence (unpublished data). The reasons for our markedly different results with apple scab are not known. One possible hypothesis could be that strains of $V$. inaequalis prevalent in Provence are somehow adapted to its dry windy climate and their pseudothecia are able to

This article is protected by copyright. All rights reserved. 
pursue their maturation even in prolonged absence of rain, possibly making use of occasional morning dew depositing on the leaf litter. This fungus is known for its adaptability to various types of selection pressure, including host resistance and presence of fungicides (de Vlas et al., 2012; Van et al., 2013). Large efforts have been dedicated to adapt apple scab models to local climate conditions with the aim of refining the predictive value of a general type of model. It can be speculated that some of the need for such adjustments could possibly also result from the particular behaviour of locally prevalent strains of the pathogen.

In conclusion, the new model presented in this study provided significantly more accurate predictions of ascospore release than the reference $\mathrm{NH}$ model in the conditions of Southern France. It has been tested since 2009 and adopted in 2013 by regional advisory services. Further work is in progress, using a similar methodological approach, to develop models based on times scales with a non-linear temperature function in other regions with contrasted climatic conditions.

\section{Acknowledgments}

The authors thank Delphine Blanke (University of Avignon, France), Aude Géa (CIRAME, France), Florent Remuson (ANSES Lyon, France) and Bernard Rouillé (SRAL DRAAF PACA, France) for their kind help with this study.

\section{References}

Alves SAM, Beresford RM, 2013. Evaluation of three models for predicting Venturia inaequalis ascospore release in Southern Brazil. New Zealand Plant Protection 66, $303-$ 7.

This article is protected by copyright. All rights reserved. 
Analytis S, 1977. Über die Relation zwischen biologischer Entwicklung und Temperatur bei phytopathogenen Pilzen. Phytopathologische Zeitschrift 90, 64-76.

Analytis S, 1979. Die Transformation von Befallswerten in der quantitativen Phytopathologie II. Das Linearisieren von Befallskurven. Phytopathologische Zeitschrift 96, 156-71.

Battilani P, Camardo Leggieri M, Rossi V, Giorni P, 2013. AFLA-maize, a mechanistic model for Aspergillus flavus infection and aflatoxin B1 contamination in maize. Computers and Electronics in Agriculture 94, 38-46.

Beresford RM, 1999. Validation of an ascospore release prediction model for apple black spot (Venturia inaequalis). New Zealand Plant Protection 52, 148-52.

Carisse O, Jobin T, Bourgeois G, 2007. Predicting apple leaf emergence from degree-day accumulation during the primary scab period. Canadian Journal of Plant Science 88, 229-38.

Carisse O, Meloche C, Boivin G, Jobin T, 2009. Action thresholds for summer fungicide sprays and sequential classification of apple scab incidence. Plant Disease, 93, 490-8.

Creemers P, van Laer S, 2006. Key strategies for reduction of the dependence on fungicides in integrated fruit production. Phytopathologia Polonica 39, 19-29.

Damos P, Savopoulou-Soultani M, 2012. Temperature-driven models for insect development and vital thermal requirements. Psyche, vol. 2012, Article ID 123405, 13 pages, 2012. doi:10.1155/2012/123405

Eikemo H, Gadoury DM, Spotts RA, Villalta O, Creemers P, Stensvand A, 2010. Evaluation of ascospore maturity models to estimate seasonal ascospore discharge of pear scab (Venturia pirina). IOBC/WPRS Bulletin 54, 41-44.

Eikemo H, Gadoury DM, Spotts RA, Villalta O, Creemers P, Stensvand A, 2011. Evaluation of six models to estimate maturation of Venturia pyrina. Plant Disease 95, 279-84.

Gadoury DM, MacHardy WE, 1982a. A model to estimate the maturity of ascospores of

This article is protected by copyright. All rights reserved. 
Venturia inaequalis. Phytopathology 72, 901-4.

Gadoury DM, MacHardy WE, 1982b. Preparation and interpretation of squash mounts of pseudothecia of Venturia inaequalis. Phytopathology 72, 92-5.

Gadoury DM, MacHardy WE, Hu C, 1984. Effects of temperature during ascus formation and frequency of ascospore discharge on pseudothecial development of Venturia inaequalis. Plant Disease 68, 223-5.

Holb IJ, Heijne B, Withagen JCM, Gáll JM, Jeger MJ, 2005. Analysis of summer epidemic progress of apple scab at different apple production systems in the Netherlands and Hungary. Phytopathology 95, 1001-20.

Holb IJ, 2008. Timing of first and final sprays against apple scab combined with leaf removal and pruning in organic apple production. Crop Protection 27, 814-22.

Jalali MA, Tirry L, Arbab A, De Clercq P, 2010. Temperature-dependent development of the two-spotted ladybeetle, Adalia bipunctata, on the green peach aphid, Myzus persicae, and a factitious food under constant temperatures. Journal of Insect Science (Madison) 10, paper 124. doi: 10.1673/031.010.12401.

James JR, Sutton TB, 1982a. Environmental factors influencing pseudothecial development and ascospore maturation of Venturia inaequalis. Phytopathology 72, 1073-80.

James JR, Sutton TB, 1982b. A model for predicting ascospore maturation of Venturia inaequalis. Phytopathology 72, 1081-5.

Kontodimas DC, Eliopoulos PA, Stathas GJ, Economou LP, 2004. Comparative temperaturedependent development of Nephus includens (Kirsch) and Nephus bisignatus (Boheman) (Coleoptera: Coccinellidae) preying on Planococcus citri (Risso) (Homoptera: Pseudococcidae): evaluation of a linear and various nonlinear models using specific criteria. Environmental Entomology 33, 1-11.

Lagarde MP, 1988. Studies on maturation of Venturia inaequalis (Cke. Wint.) ascospores

This article is protected by copyright. All rights reserved. 
modelling. Proceedings of the Second international conference on plant diseases, 1988. Bordeaux: ANPP, Paris (France), 1093-8.

Legler SE, Caffi T, Rossi V, 2012. A nonlinear model for temperature-dependent development of Erysiphe necator chasmothecia on grapevine leaves. Plant Pathology 61, 96-105.

Lovell DJ, Powers SJ, Welham SJ, Parker SR, 2004. A perspective on the measurement of time in plant disease epidemiology. Plant Pathology 53, 705-12.

Marquardt DW, 1963. An algorithm for least-squares estimation of nonlinear parameters. Journal of the Society for Industrial and Applied Mathematics 11, 431-41.

Rossi V, Ponti I, Marinelli M, Giosue S, Bugiani R, 2000. A new model estimating the seasonal pattern of air-borne ascospores of Venturia inaequalis (Cooke) Wint. in relation to weather conditions. Journal of Plant Pathology 82, 111-8.

Rossi V, Salinari F, Pattori E, Giosue S, Bugiani R, 2009. Predicting the dynamics of ascospore maturation of Venturia pirina based on environmental factors. Phytopathology 99, 453-61.

Schwabe WFS, Jones AL, van Blerk E, 1989. Relation of degree-day accumulations to maturation of ascospores of Venturia inaequalis in South Africa. Phytophylactica 21, 136.

Sheskin DJ, 2007. Measures of Association/Correlation. In. Handbook of Parametric and Nonparametric Statistical Procedures, Fourth Edition. Chapman \& Hall/CRC, 1219416.

Stensvand A, Eikemo H, Gadoury DM, Seem RC, 2005. Use of a rainfall frequency threshold to adjust a degree-day model of ascospore maturity of Venturia inaequalis. Plant Disease 89, 198-202.

Stensvand A, Gadoury DM, Amundsen T, Seem RC, 2006a. An adaptation of the New

This article is protected by copyright. All rights reserved. 
Hampshire degree-day model to predict ascospore release of Venturia inaequalis in Norway. Bulletin OILB/SROP 29(1), 75-81.

Stensvand A, Eikemo H, Gadoury DM, Seem RC, 2006b. Climatic conditions prior to green tip of apple affect ascospore maturation in Venturia inaequalis. Bulletin OILB/SROP 29(1), 243-7.

Stensvand A, Gadoury DM, Amundsen T, Semb L, Seem RC, 1997. Ascospore release and infection of apple leaves by conidia and ascospores of Venturia inaequalis at low temperatures. Phytopathology 87, 1046-53.

Van AL, Caffier V, Lasserre-Zuber P, Chauveau A, Brunel D, Le Cam B, Durel C-E, 2013. Differential selection pressures exerted by host resistance quantitative trait loci on a pathogen population: a case study in an apple $\mathrm{x}$ Venturia inaequalis pathosystem. New Phytologist 197, 899-908.

Vlas M de, Jong PF de, Heijne B, 2012. Strategies for using plant protection products against apple scab (Venturia inaequalis) to avoid resistance development. Bulletin OILB/SROP 84, 127-31.

Xu XM, Butt DJ, Van Santen G, 1995. A dynamic model simulating infection of apple leaves by Venturia inaequalis. Plant Pathology 44, 865-76.

Xu XM, 1996. On estimating non-linear response of fungal development under fluctuating temperatures. Plant Pathology 45, 163-71.

Zou KH, Tuncali K, Silverman SG, 2003. Correlation and simple linear regression. Radiology 227, 617-22.

This article is protected by copyright. All rights reserved. 
Table 1: Definition of the temperature functions $(R)$ used for determining the daily rate of pseudothecial maturation and assessment of the link between ascospore release dynamics and thermal time scales.

\begin{tabular}{|c|c|c|c|c|}
\hline $\begin{array}{l}\text { Type of thermal time } \\
\text { scale }\end{array}$ & Equation of the $R(T)$ function ${ }^{x}$ & $\begin{array}{l}\text { Paramete } \\
\text { rs } \\
\text { providing } \\
\text { the } \\
\text { highest } \rho \\
\text { value }^{x}\end{array}$ & Biofix & $\begin{array}{l}\text { Spearman's } \\
\text { rank } \\
\text { correlation } \\
\text { coefficient } \rho\end{array}$ \\
\hline \multirow[t]{2}{*}{$\begin{array}{l}\text { NH (degree-days - } \\
\text { base 0) (Gadoury \& } \\
\text { MacHardy, 1982a) }\end{array}$} & \multirow[t]{2}{*}{$\mathrm{R}(T)=T$ if $T>0 \mathrm{C} ; 0$ otherwise } & \multirow[t]{2}{*}{ reference } & $\begin{array}{l}\text { First } \\
\text { observati } \\
\text { on of } \\
\text { mature } \\
\text { ascospor } \\
\text { es }\end{array}$ & 0.877 \\
\hline & & & $\begin{array}{l}\text { January } \\
1^{\text {st }}\end{array}$ & 0.875 \\
\hline $\begin{array}{l}\text { James \& Sutton } \\
\text { (James \& Sutton, } \\
\text { 1982a, 1982b) }\end{array}$ & $\mathrm{R}(T)=0.0031+0.0546 * T-0.00175 * T^{2}$ & reference & $\begin{array}{l}\text { January } \\
1^{\text {st }}\end{array}$ & 0.911 \\
\hline "ABCD" & $\begin{array}{l}\mathrm{R}(T)=\{(T-a) /(b-a) \text { if }(T>a \text { and } T<b) ; 0 \text { otherwise }\} \\
+\{1 \text { if }(T>=b \text { and } T<=c) ; 0 \text { otherwise }\}+\{(-T+d) /(d \\
-c) \text { if }(T>c \text { and } T<d) ; 0 \text { otherwise }\}\end{array}$ & $\begin{array}{l}a=-4 \\
b=5 \\
c=23 \\
d=31\end{array}$ & $\begin{array}{l}\text { January } \\
1^{\text {st }}\end{array}$ & 0.926 \\
\hline $\begin{array}{l}\text { Analytis (Analytis, } \\
\text { 1977) }\end{array}$ & $\begin{array}{l}\mathrm{R}(T)=\mathrm{k}^{*}(T-a)^{\mathrm{b}} *(c-T)^{\mathrm{d}} \text { if } T>a \text { or } T<c ; 0 \\
\text { otherwise }\end{array}$ & $\begin{array}{l}a=5 \\
b=0.96 \\
c=59 \\
d=2.51 \\
k= \\
230000\end{array}$ & $\begin{array}{l}\text { January } \\
1^{\text {st }}\end{array}$ & 0.922 \\
\hline Modified Gauss & $\mathrm{R}(T)=\left(1 /\left(1+a^{(b-T)}\right)\right) * \exp \left(-(T-c)^{2} / d^{2}\right)$ & $\begin{array}{l}a=2.1 \\
b=-1 \\
c=10 \\
d=15\end{array}$ & $\begin{array}{l}\text { January } \\
1^{\text {st }}\end{array}$ & 0.924 \\
\hline
\end{tabular}

${ }^{\mathrm{x}} T=$ average daily temperature (expressed in ${ }^{\circ} \mathrm{C}$ ); $a, b, c, d=$ parameters of the $\mathrm{R}(T)$ equations

This article is protected by copyright. All rights reserved. 
Table 2: Ascospore release by Venturia inaequalis (1996 to 2013) from apple leaves collected each autumn in an untreated organic orchard (cv Golden Delicious) and stored on the ground near a weather recording station in Avignon, France

\begin{tabular}{|c|c|c|c|c|}
\hline Year & $\begin{array}{l}\text { Date of } \\
\text { observation of first } \\
\text { mature ascospores }\end{array}$ & $\begin{array}{l}\text { Date of first } \\
\text { ascospore release }\end{array}$ & $\begin{array}{l}\text { Date of last } \\
\text { ascospore release }\end{array}$ & $\begin{array}{l}\text { Cumulated ascospore } \\
\text { counts over the } \\
\text { season }\end{array}$ \\
\hline 1996 & 15 February & 27 February & 2 June & 15155 \\
\hline 1997 & 24 February & 16 March & 18 May & 7466 \\
\hline 1998 & 2 March & - & - & $<500$ \\
\hline 1999 & 24 February & 26 March & 7 June & 10439 \\
\hline 2000 & 23 February & 2 April & 9 May & 610 \\
\hline 2001 & 19 February & 27 February & 10 June & 34519 \\
\hline 2002 & 20 February & 15 March & 23 May & 6062 \\
\hline 2003 & 7 March & - & - & $<500$ \\
\hline 2004 & 27 February & 23 February & 8 June & 48443 \\
\hline 2005 & 27 March & 8 April & 1 June & 626 \\
\hline 2006 & 3 March & 20 March & 20 May & 7357 \\
\hline 2007 & 16 February & 6 March & 7 May & 5875 \\
\hline 2008 & 7 February & 9 March & 5 May & 7433 \\
\hline 2009 & 16 February & 3 March & 15 May & 25668 \\
\hline 2011 & 12-13 March & 15 March & 19 May & 17247 \\
\hline 2012 & 12 March & 1 April & 31 May & 816 \\
\hline 2013 & 15 February & 9 March & 11 May & 2822 \\
\hline
\end{tabular}

This article is protected by copyright All rights reserved. 
Table 3: Validation (with observed data from 2009-2013 seasons) of the models developed in the present study for the prediction of ascospore release by Venturia inaequalis. The temperature functions of the NH-based and ABCD-based models are defined in Table 1. The rABCD-based model was constructed from the improved rain sensitive $A B C D$ thermal time scale as described in the Materials and Methods section.

\begin{tabular}{|c|c|c|c|c|c|c|}
\hline \multirow[b]{2}{*}{ Model / year } & \multicolumn{4}{|c|}{ Residuals $^{x}$} & \multirow[b]{2}{*}{$\begin{array}{l}\text { Number of } \\
\text { overestimates }\end{array}$} & \multirow[b]{2}{*}{$\begin{array}{l}\text { Number of } \\
\text { underestimates }\end{array}$} \\
\hline & $\begin{array}{l}\text { Average } \\
\text { of } \\
\text { absolute } \\
\text { values }\end{array}$ & $\begin{array}{l}\text { Maximum } \\
\text { positive }\end{array}$ & $\begin{array}{l}\text { Maximum } \\
\text { negative }\end{array}$ & $\begin{array}{l}\text { Amplitude } \\
\text { of } \\
\text { deviation }\end{array}$ & & \\
\hline
\end{tabular}

$\mathrm{NH}$-based reference model

\begin{tabular}{|r|c|c|c|c|c|c|}
\hline 2009 & 10.50 & - & -60.20 & 60.2 & $9 / 9$ & - \\
\hline 2011 & 16.80 & - & -64.40 & 64.4 & $9 / 9$ & - \\
\hline 2012 & 27.90 & - & -57.80 & 57.8 & $13 / 14$ & $1 / 16$ \\
\hline 2013 & 12.70 & 0.50 & -32.50 & 33.0 & $15 / 16$ & \\
\hline
\end{tabular}

ABCD-based model

\begin{tabular}{|r|c|c|c|c|c|c|}
\hline 2009 & 12.70 & 30.30 & -2.40 & 32.7 & $2 / 9$ & $7 / 9$ \\
\hline 2011 & 12.10 & 23.70 & -24.40 & 48.1 & $3 / 9$ & $6 / 9$ \\
\hline 2012 & 16.45 & - & -32.50 & 32.5 & $13 / 14$ & - \\
\hline 2013 & 5.02 & 7.90 & -18.00 & 25.9 & $10 / 16$ & $6 / 16$ \\
\hline
\end{tabular}

rABCD-based model

\begin{tabular}{|r|r|r|r|r|r|c|}
\hline 2009 & 4.67 & 7.71 & -10.62 & 18.33 & $2 / 9$ & $7 / 9$ \\
\hline 2011 & 11.05 & 29.93 & -14.39 & 44.32 & $3 / 9$ & $6 / 9$ \\
\hline 2012 & 9.85 & 1.95 & -20.76 & 22.71 & $13 / 14$ & $1 / 14$ \\
\hline 2013 & 4.89 & 3 & -19.5 & 22.5 & $11 / 16$ & $4 / 16$ \\
\hline
\end{tabular}

${ }^{\mathrm{x}}$ Residuals $=$ difference between observed and predicted values of percent cumulated ascospore release shown in Figure 7

This article is protected by copyright All rights reserved. 
Table 4: Assessment of possible benefits gained by taking into account the occurrence of periods of dryness during the ascospore release period. Spearman's rank correlation $\boldsymbol{\rho}$ was used to quantify the link between the dynamics of ascospore release and the thermal time scales.

\begin{tabular}{|l|l|c|c|}
\hline \multirow{2}{*}{ Type of thermal time scale } & \multirow{2}{*}{ Type of biofix } & \multicolumn{2}{|l|}{$\begin{array}{l}\text { Climatic factors taken into account to adjust the } \\
\text { time scale }\end{array}$} \\
\cline { 3 - 4 } & & Temperature only & $\begin{array}{l}\text { Temperature + dry } \\
\text { days }\end{array}$ \\
\hline \multirow{2}{*}{$\mathrm{NH}$ (degree-days - base 0) } & $\begin{array}{l}\text { First observation of } \\
\text { mature ascospores }\end{array}$ & 0.877 & 0.843 \\
\cline { 2 - 4 } & 1 January & 0.875 & 0.847 \\
\hline ABCD-based & $\begin{array}{l}\text { First observation of } \\
\text { mature ascospores }\end{array}$ & 0.923 & 0.723 \\
\cline { 2 - 4 } & 1 January & 0.926 & 0.721 \\
\hline
\end{tabular}

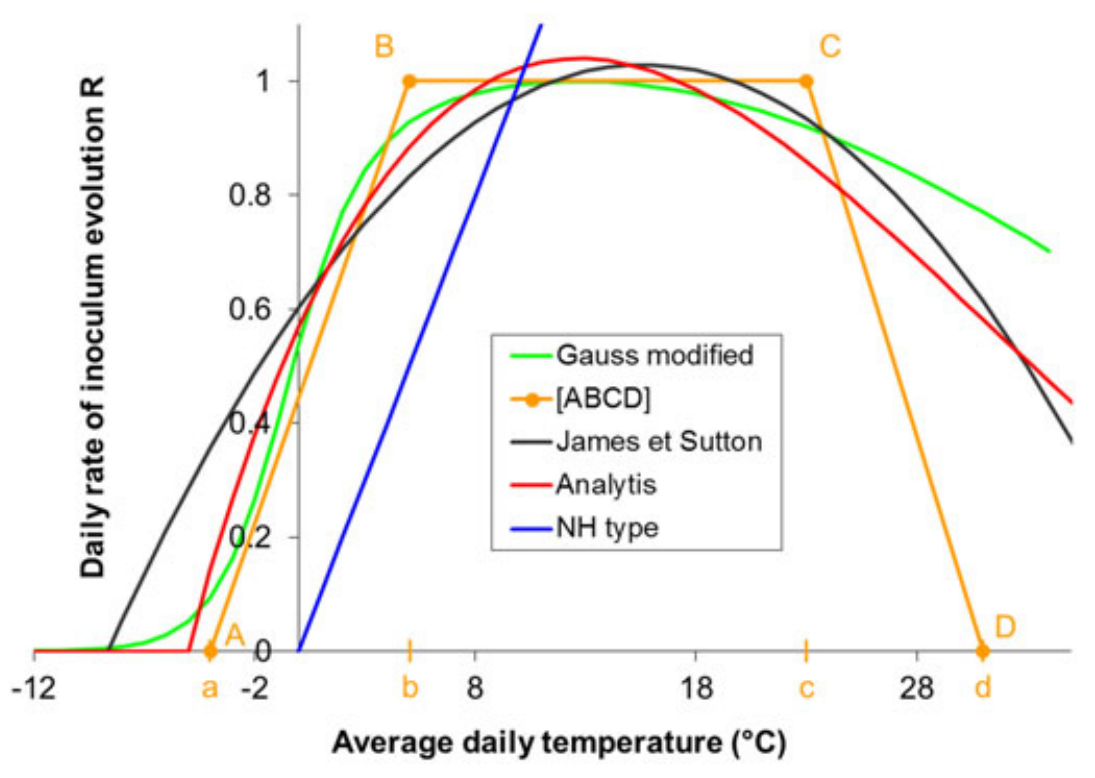

This article is protected by copyright. All rights reserved. 

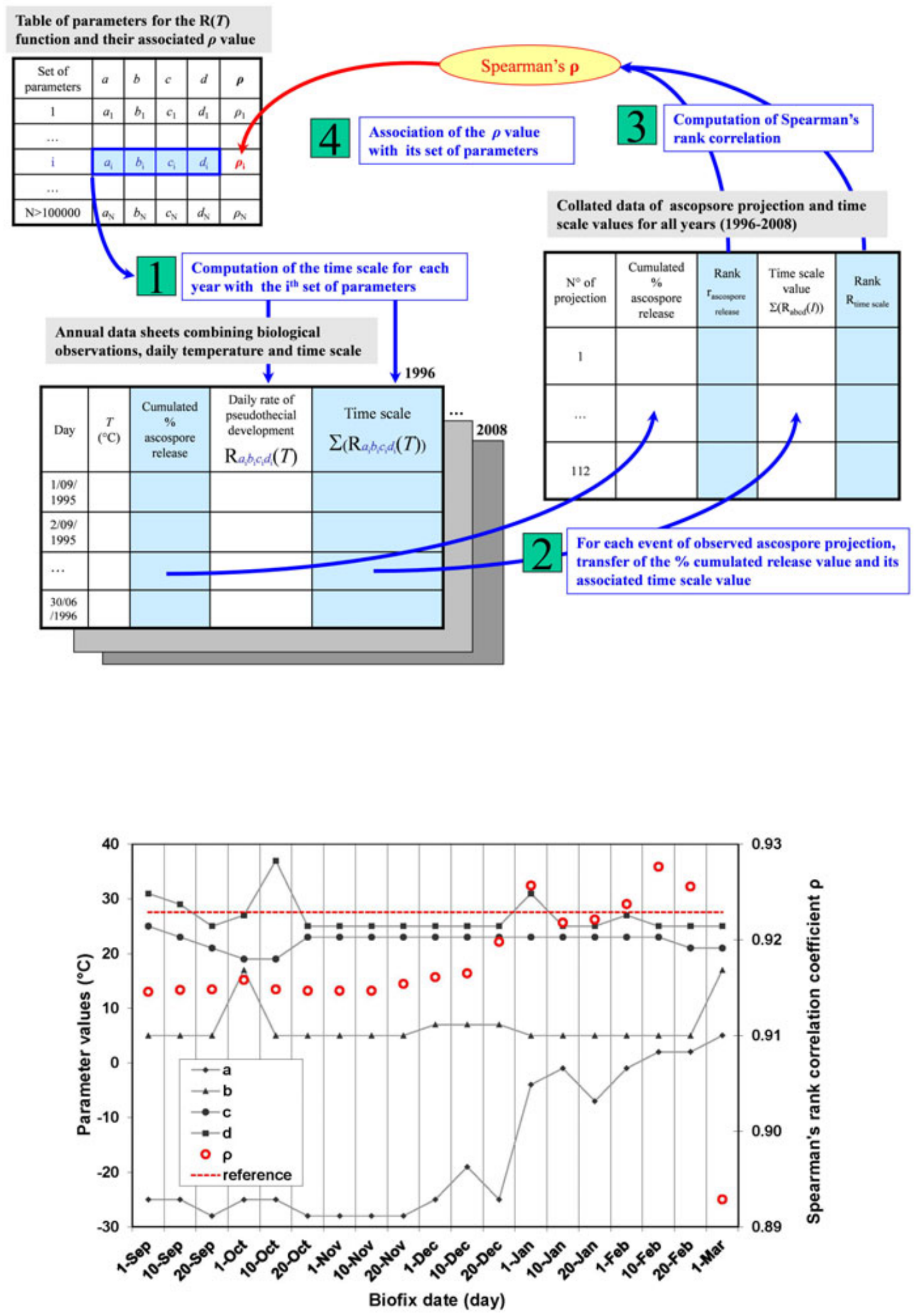

ำ

This article is protected by copyright All rights reserved.

Roubal, C., Nicot, P. C. (Auteur de correspondance) (2016). Apple scab: numerical optimization of a new thermal time scale and application for modelling ascospore release in southern France. 

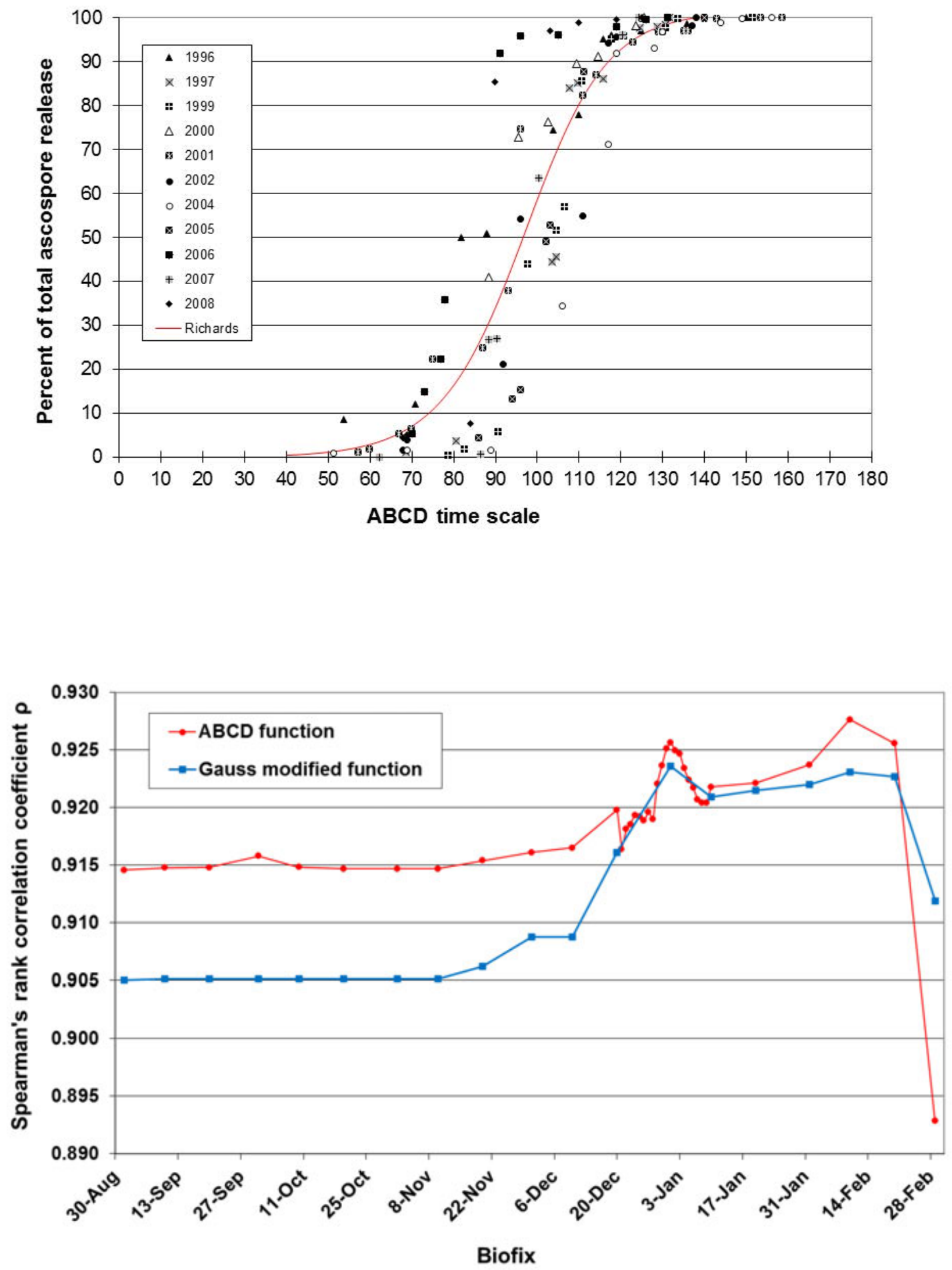

This article is protected bycopyright All rights reserved.

Roubal, C., Nicot, P. C. (Auteur de correspondance) (2016). Apple scab: numerical optimization of a new thermal time scale and application for modelling ascospore release in southern France. 

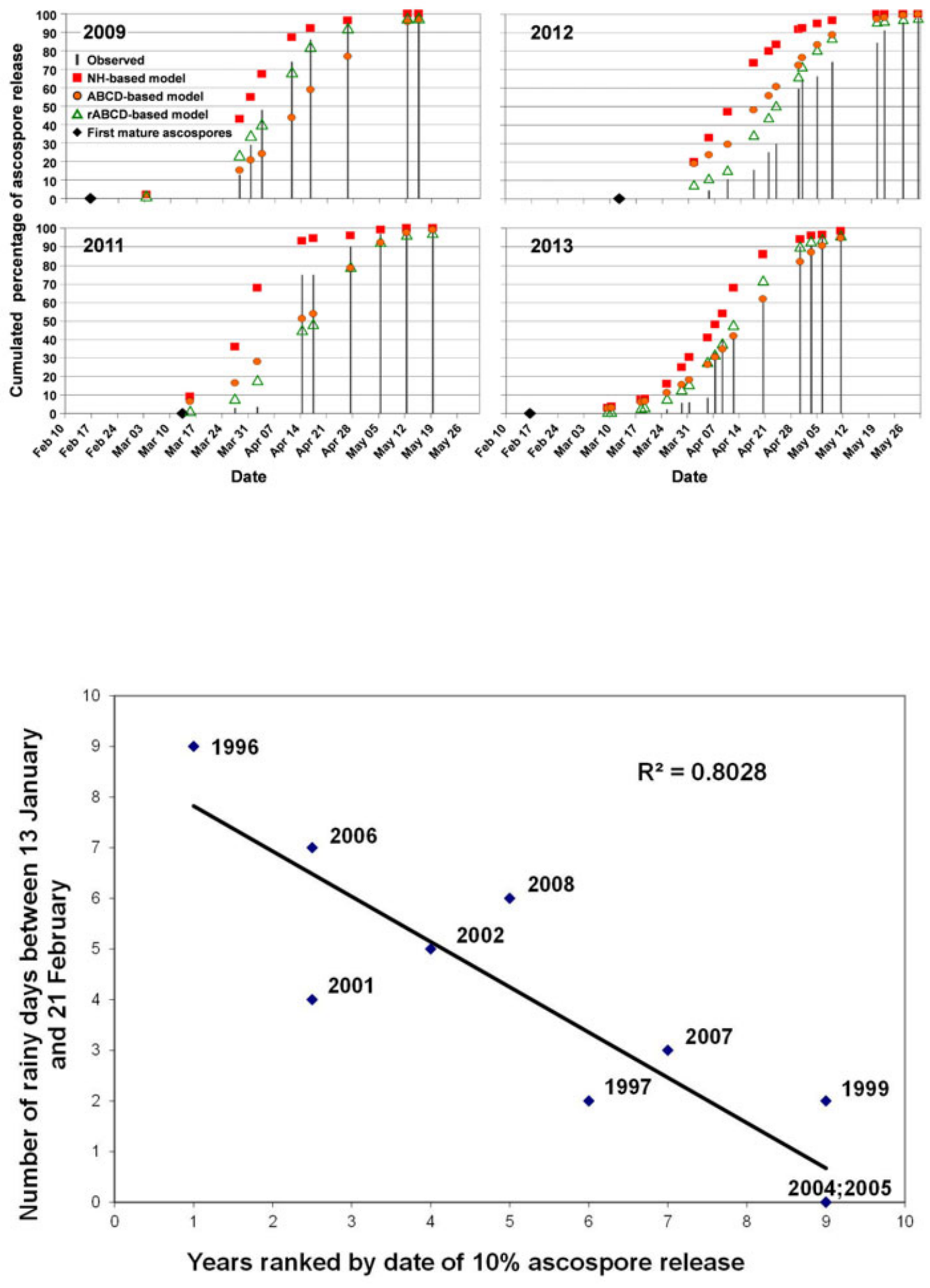

This article is protected by copyright. All rights reserved. 


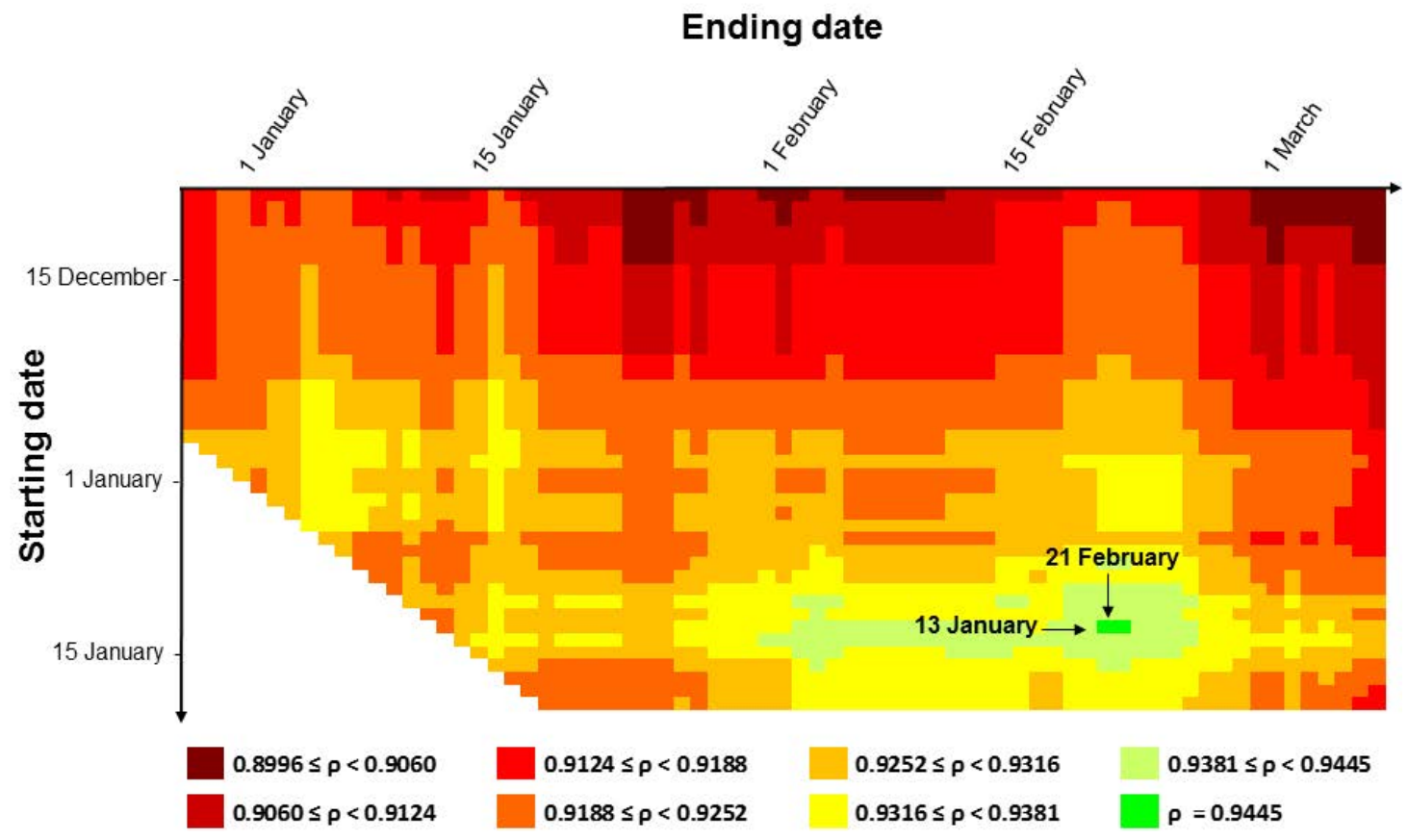

This article is protected by copyright All rights reserved.

Roubal, C., Nicot, P. C. (Auteur de correspondance) (2016). Apple scab: numerical optimization of a new thermal time scale and application for modelling ascospore release in southern France. Plant Pathology, 65 (1), 79-91. , DOI : 10.1111/ppa.12398 